\title{
Cumulative species description curve of Corotocini (Aleocharinae, Staphylinidae) and prospects for the future
}

\author{
Igor Eloi ${ }^{* *} \bullet$, Carlos Pires-Silvab®, Bruno Zilbermanc® \\ a Programa de Pós-Graduação em Ecologia e Conservação, Universidade Estadual da Paraíba, Campina Grande, 58429-500, \\ Paraíba, Brasil.*eloi.igor@yandex.com \\ b Laboratório de Ecologia de Térmitas, Universidade Estadual da Paraíba, Campina Grande, 58429-500, Paraíba, Brasil. \\ c Programa de Pós-Graduação em Sistemática, Taxonomia Animal e Biodiversidade, Museu de Zoologia da Universidade de São \\ Paulo, 04263-000, São Paulo, Brasil.
}

Received: February 12, 2020 / Accepted: April 14, 2020 / Published online: May 25, 2020

\begin{abstract}
This study deals with the global estimation of the species of Corotocini (Aleocharinae) based on taxonomic description rates. We estimate the maximum number of possible extant species by maximum likelihood using the Michaelis-Menten model fitted into a non-linear regression. Although the studies regarding Corotocini are majorly taxonomic descriptions, the results suggest that there are many yet undescribed species, We also highlight that the basic knowledge regarding these organisms ecology is fairly obscure. Since the discovery of the first organism living in association with termites, the taxonomic effort hasn't been constant along the years, and although our results suggest that many species lie undiscovered, the lack of specialized professionals can compromise the actual knowledge regarding their biodiversity. Besides that, we comment on the future of this field and the lack of specimens from various locations.
\end{abstract}

Keywords: Coleoptera, michaelis-menten, taxonomic effort, termitophiles.

\section{Curva cumulativa de descrição de espécies de Corotocini (Aleocharinae, Staphylinidae) e perspectivas para o futuro}

\begin{abstract}
Resumo
Este estudo trata da estimativa global das espécies de Corotocini (Aleocharinae) com base nas taxas de descrição taxonômica. Estimamos o número máximo possível de espécies existentes por probabilidade máxima usando o modelo de Michaelis-Menten ajustado em a uma regressão não-linear. Apesar dos trabalhos envolvendo Corotocini serem majoritariamente taxonômicos, os resultados sugerem que ainda existem muitas espécies sem descrição, além de que o conhecimento básico a respeito da ecologia destes organismos seja bastante obscuro. Desde a descoberta dos primeiros organismos vivendo em associação com cupins, o esforço taxonômico dedicado a esse grupo não foi constante com o passar dos anos, e apesar de os resultados sugerirem que muitas espécies ainda podem ser descobertas, a falta de profissionais especializados no grupo pode comprometer o conhecimento real acerca de diversidade destes organismos. Além disso, comentamos o futuro desse campo de estudo e a falta de espécimes de outras localidades.
\end{abstract}

Palavras-chave: Coleoptera, michaelis-menten, esforço taxonômico, termitófilos.

\section{Introduction}

In 1853 the Danish entomologist Jørgen Matthias Schiødte published the first report of other insects living in association with termites (Schiødte, 1853), and spawned an entire field of studies. He established the genera Corotoca and Spirachtha, from Brazil, with the description of C. melantho, C. phylo and $S$. eurymedusa, the first known termitophiles - according to Kanao et al (2016), termitophily can be described as "the symbiosis of organisms with termite societies".

Since Schiødte's work, more than 200 species have been described so far, all termitophilous (Seevers, 1957; Kistner, 1969). They are included in the tribe Corotocini (Coleoptera,
Staphylinidae, Aleocharinae), the highly specialized group of termitophilous rove beetles, with mostly pantropical distribution, and are characterized by the mentum fused to submentum (postmentum), mesocoxae free and the presence of at least some degree of physogastry (Seevers, 1957).

Some important and rather remarkable scientists were responsible for the growing taxonomic knowledge of the tribe. Despite the numerous species described, it is worth mention the pinnacles of the study of this field, first being the monograph on termitophilous Staphylinidae published by Charles H. Seevers (1957) and second the monograph including a revision and systematic analysis of the tribe 
Corotocini by Herbert R. Jacobson, David H. Kistner and Jacques M. Pasteels (1986). These monographical works shed light on the taxonomical uncertainty that naturally grows alongside years of a continuous description of new taxa.

Whether we are sampling from the field or studying material deposited in collections we frequently find specimens of Corotocini belonging to an undescribed species, or of a doubtful identification. Considering that taxonomic rates tend to be correlated with time, and decrease in function of taxonomic completeness (Pine, 1994; Paxton, 1998), we try to understand how well we know the diversity of Corotocini and also how the taxonomic effort evolved through time since Schiødte`s first publication. Moreover, we also address future prospects for the field of termitophily studies.

\section{Materials and Methods}

\section{Definitions of terms}

We will treat the year of the description as a species discovery unit. The term "taxonomic effort" refers to the number of species described in a time unit.

We refer to a colony as a self-organized entity composed of termites closely related to themselves. Nests are treated here as buildings made by the termites, underground or wood borrows that the insects may live in. Termitophiles are the organisms that manage to integrate and are obligatorily associated with the society of termites. They are tolerated, fed and many times carried by the termites (Kistner 1969).

\section{Data sampling}

The data used in this study comes from a taxonomic catalog developed by the authors (in. prep), mainly from information collected from current literature, gathered mainly from Google Scholar and the library from the Museu de Zoologia da Universidade de São Paulo. Some literature were sent by foreign fellow researchers. The catalog also contains a number of unpublished observations made by the authors.

The number of species described per year was cumulatively summed in order to construct a growing vector with the origin at the first description date $\left(\mathrm{t}_{0}\right)$. Our $x$-var is the known period of taxonomic descriptions $\left(\mathrm{t}_{0}-\mathrm{t}_{\mathrm{n}}\right)$, and ranges from the first known description (Schiødte, 1853), to the current last description (Zilberman, 2019). The data was conveniently sorted into six categories representing zoogeographical regions of the globe according to their type-locality.

\section{Statistical analysis}

We address the first question by fitting a Michaelis-Menten model into a Non-Linear Regression using the dose-response analysis routines (drc package). Classically, the MichaelisMenten model consists in a two-parameter model where Smax is the maximum species existing and $B$ is a measure of halfway through $Y$ (Colwell \& Coddington, 1994). Although there have been proposition of other methods richness estimation based on taxonomic description rate (Solow and Smith, 2005), the Michaelis-Menten model is intuitive, clear and straightforward and continues to be used in studies with the aim of estimating maximum and median values such as in biochemistry (Johnson, 2013), ecology (Reich et al., 2012), and taxonomic description rate (Constantino, 2017).

The usual two-parameter approach failed to describe the behavior of our data, fitting poorly and failing to predict correct values. A three-parameter Michaelis-Menten (Ritz et al., 2020) fitted the data much better. The third parameter, $a$, is a negative value and therefore meaningless in our interpretation. In addition, we calculated robust estimations for the standard error of Smax using the Wald (quasi) $t$ test.

The reason to use the Michaelis-Menten model lies on the rationality that there is a fixed number of existing species in the world. The logic is that once we know all the elements in the species pool, the curve of accumulation of species descriptions per year would reach an asymptote. This method has been used in a series of studies that dealt with estimating the total biodiversity of a taxonomic group (Colwell and Coddington, 1994; Constantino, 2018).

The hypotheses tested to answer our second question follows the natural assumption that the rate of taxonomic effort would follow a positive steeped curve until reaching a point where the majority of species have been described, then the curve would slowly drop, reaching a negative correlational state with the time variable. In order to test this hypothesis, we computed Spearman's rank correlation $(\rho)$ between the absolute number of species described per year and time. All analysis were performed in R version 3.6.2 ( $\mathrm{R}$ Core Team, 2020).

\section{Results and Discussion}

There are registers of 214 species in 64 genera classified in the Corotocini tribe. Our model predicts that the cumulative description curve could reach an asymptote at $3743 \pm 143$ species $(\mathrm{t}=26.214 ; \mathrm{p}<0.001)$. An estimation so far away from the known quantity of described species indicates that we have poor knowledge of the true biodiversity of these social parasites.

While the Michaelis-Menten model tends to extrapolate the estimations at early stages due to irregular accumulation rate, the model applied to our data proved to be reliable for estimations that are not too far ahead in time. At the current rate, we could expect to have around 267 described species by 2050 (Figure 1).

When we organize the data into cumulative description curves factored by the regions, it becomes very clear that really only two regions have had taxonomic attention (Figure 2). The majority of known species are Neotropical (51.4\%), potentially housing a maximum of $1688 \pm 205$ species $(\mathrm{t}=8.21 ; \mathrm{p}<0.001)$, followed by the Afrotropical region $(29.9 \%)$, potentially housing $1360 \pm 89$ species $(\mathrm{t}=15.212$; $\mathrm{p}<0.001)$, and the Oriental $(6.64 \%)$. The Nearctic region has a lesser number of described species (only 4 known species). Michaelis-Menten model could only be used with confidence in the Neotropical and Afrotropical regions, due to the low species richness known for the other four zoogeographical regions.

In the Neotropical region, the efforts of late termitologists Renato L. Araújo and Alfred E. Emerson have 
resulted in a wealth of knowledge about termitophiles (Seevers, 1957). They had the habit to sample not only termites but also the guests inhabiting the nest. A habit that appears to have been lost over time. A large part of the termitophiles deposited at the Museu de Zoologia da Universidade de São Paulo was sampled by Dr. Araújo.

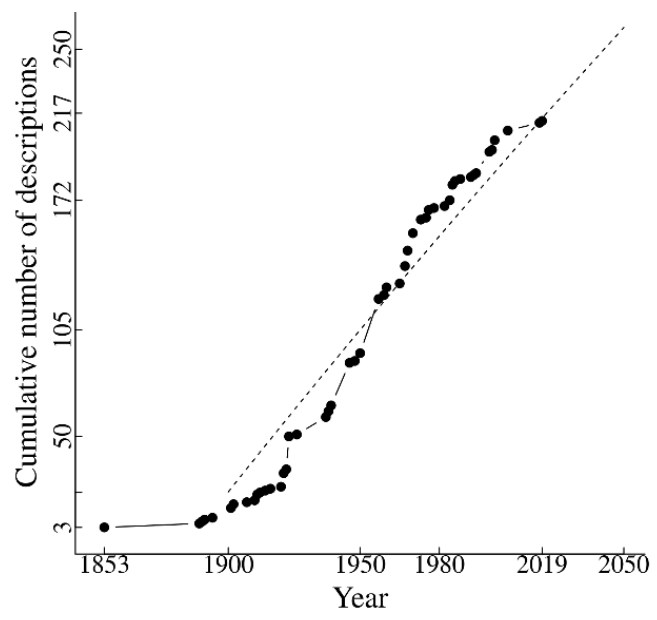

Figure 1. Cumulative species description curve for the Corotocini of the world. The dashed curve is the Michaelis-Menten fitted.

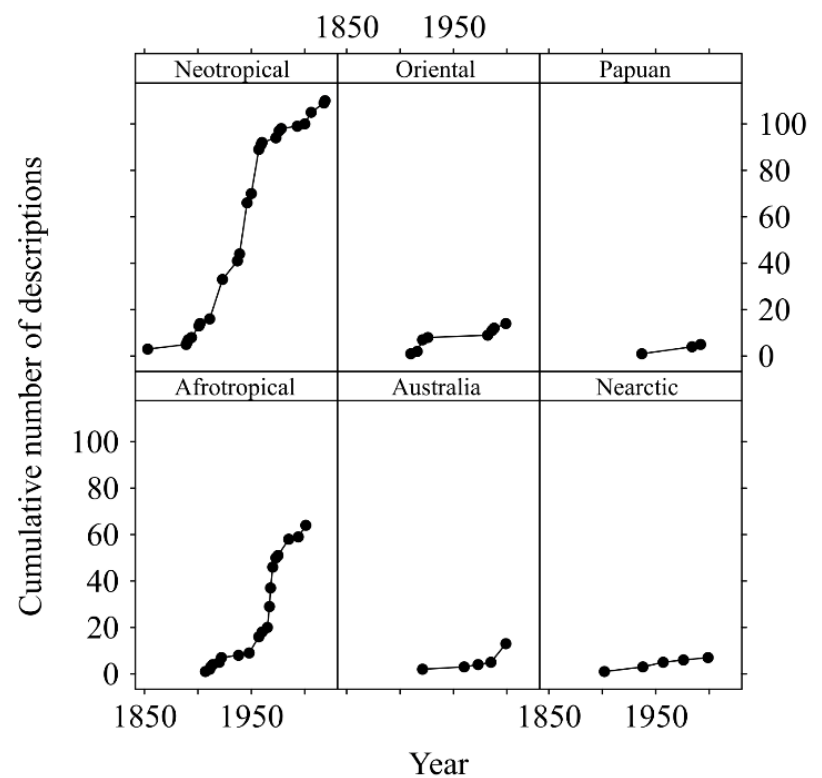

Figure 2. Cumulative species description curves across the years separated by zoogeographical regions.

David H. Kistner's expedition to Africa resulted in a large number of species described to that continent (Kistner, 1968a, 1968b, 1973a, 1973b). Kistner's work must be highlighted due to the invaluable observations he wrote about the behavior of these beetles, something of utmost importance (Kistner, 1979, 1982).

The worldwide rate of taxonomic description across the year hasn't been constant, nor follows a pattern (positive or negative) $(\rho=0.17, \mathrm{~S}=15154, \mathrm{P}=0.22)$, hinting that we are far from reaching robust knowledge on the true diversity of the group. The very inconstant rate of taxonomic description could possibly explain the difficulty in fitting the traditional two-parameter Michaelis-Menten model.

The peak of taxonomic effort so far was reached between 1930 and 1970, the time period when Charles Seevers and David Kistner were most active. Since their retirement, the taxonomic effort has dropped (Figure 3).

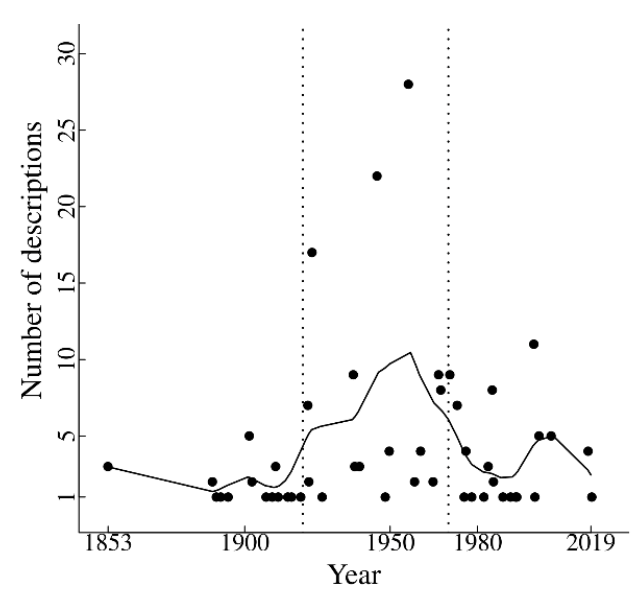

Figure 3. Description rate across the years. Data points are the number of species described in a given year. The line was fitted using a loess algorithm and serves as a visual estimation of tendency in the taxonomic effort. Vertical lines delimit peak taxonomic effort (1930 to 1970s).

There are very few studies that deal somehow with the general diversity of Corotocini (Perhaps only Seevers (1957), did really catch a glance of the problem). However, the experiments we have conducted have shown a surprising diversity of termitophile staphilinids living in association with two Nasutitermes Dudley species in Northeastern Brazil (Pires-Silva et al., unpublished data). This scenario is likely to be found in other areas of Brazil that, like the Northeastern domains, haven't been thoroughly sampled.

Brazil, particularly, harbors the major part of the Amazon rainforest, regarded by the scientific community to be the tropical forest with the highest number of endemism, in addition to being the largest biodiversity hotspot on the planet (Paviolo et al., 2016). Although several expeditions have been carried out as part of researches in the Brazilian Amazon, only a few samples of termitophiles are from the Brazilian territory (Seevers, 1957). This phenomenon can be linked to three factors: I) The active termitologists in that region weren't probably familiar with the habit of sampling non-termitid organisms associated with termites; II) Collection of termitophiles requires a certain level of experience since these organisms commonly display some degree of morphological resemblance to their host (Kistner, 1979; Cunha et al., 2015); III) The number of experts in the field is very small, limiting the number of samplings aimed at termitophiles.

The small number of Corotocini known in the Oriental region must be highlighted because, contradictorily this region houses many termite species (Jones and Eggleton, 2010; Constantino, 2018). This region has been especially neglected regarding the true diversity of Corotocini. Either 
the inquilines haven't been collected in the numerous termite diversity studies realized in the Orient or the material is stored in taxonomic collections and haven't been studied by taxonomists.

A large amount of material can be assembled by studies of ecology and behavior. During the last century, the majority of papers published about these beetles have dealt with taxonomic descriptions and revisions (Seevers, 1957; Jacobson et al., 1986).

Despite some sporadic observations, only recently researches have invested time in investigating and reasoning about the biology and host-parasite interactions, mainly aimed at the model organism beetles of the Corotoca genus and its termite host Constrictotermes cyphergaster (Zilberman et al., 2019). The studies that deal with elucidating the behavior and social-integration of these beetles could be an interesting way to gather samples, understanding the biology of termitophilous organisms and give a wider picture of the true diversity of these beetles.

\section{Conclusion}

We haven't reached a point where we know the majority of species of Corotocini present in nature; in fact, the estimates point out that we have a piece of very poor knowledge about the true diversity of the group. The work involving these organisms should be explored beyond taxonomic purposes since the ecology and behavior of the major part of these organisms are still largely unknown.

Too few professionals have been constantly studying the group, and most of the material deposited in collections had been collected by termitologists. Thus, we hope that the next generations of termite researchers will pay attention to also collect all the organisms that can be found inside the nest, allowing new discoveries and also linkages between researchers from different groups, making fields such as sociability and parasite-host systems better understood.

\section{References}

Colwell, R. K., \& Coddington, J. A. (1994). Estimating terrestrial biodiversity through extrapolation. Philosophical Transactions of the Royal Society of London. Series B: Biological Sciences, 345(1311), 101-118. doi:10.1098/rstb.1994.0091

Constantino, R. (2018). Estimating Global Termite Species Richness Using $\begin{array}{llll}\text { Extrapolation. } & \text { Sociobiology, } & 65(1), & 10-14 .\end{array}$ doi:10.13102/sociobiology.v65i1.1845

Cunha, H. F. D., Lima, J. S., Souza, L. F. d., Santos, L. G. A. D., \& Nabout, J. C. (2015). No Morphometric Distinction between the Host Constrictotermes cyphergaster (Silvestri) (Isoptera: Termitidae, Nasutitermitinae) and its Obligatory Termitophile Corotoca melantho Schiødte (Coleoptera: Staphylinidae). Sociobiology, 62(1), 65-69. doi:10.13102/sociobiology.v62i1.65-69

Jacobson, H., Kistner, D. , \& Pasteels, J. M. (1986). Generic Revision, Phylogentic Classification, and Phylogeny of the Termitophilous Tribe Corotocini (Coleoptera: Staphylinidae). Sociobiology, 12(1), 1-239. doi:10.1016/j.febslet.2013.07.012

Johnson, K. A. (2013). A century of enzyme kinetic analysis, 1913 to 2013. FEBS Letters, 587(17), 2753-2766. doi:10.1016/j.febslet.2013.07.012

Jones, D. T. , \& Eggleton, P. (2010). Global biogeography of termites: a compilation of sources. In Biology of termites: a modern synthesis, pages 477-498. Springer.

Kanao, T., Eldredge, K., \& Maruyama, M. (2016). A defensive body plan was pre-adaptive for termitophily in the rove beetle tribe Termitohospitini (Staphylinidae: Aleocharinae). BioRxiv, 083881. doi:10.1101/083881

Kistner, D. H. (1968a). Revision of the African Species of the Termitophilous
Tribe Corotocini (Coleoptera: Staphylinidae). I. A New Genus and Species from Ovamboland and Its Zoogeographic Significance. Journal of the New York Entomological Society, 76(3), 213-221.

Kistner, D. H. (1968b). Revision of the African Species of the Termitophilous Tribe Corotocini (Coleoptera, Staphylinidae) II. The Genera Termitomimus Trägårdh and Nasutimimus New Genus and Their Relationships. Coleopterists Bulletin, 22(3), 65-93.

Kistner, D. H. (1969). The Biology of Termitophiles. In K. Krishna \& F. M. Weesner (Eds.), Biology of Termites (pp. 525-557). Academic Press doi:10.1016/B978-0-12-395529-6.50021-0

Kistner, D. H. (1973a). The termitophilous Staphylinidae associated with Grallatotermes in Africa; their taxonomy, behavior and a surver of their glands of external secretion. Annals of the Entomological Society of America, 66(1), 197 - 222.

Kistner, D. H. (1973b). The termitophilous Staphylinidae from Angola (Coleoptera). Publicações Culturais da Companhia de Diamantes de Angola, 86, 99-164.

Kistner, D. H. (1979). Social and evolutionary significance of social insect symbionts. In Hermann, H. R., editor, Social insects, volume I, pages 1-244. Academic Press, New York.

Kistner, D. H. (1982). The social insect's bestiary. In Hermann, H. R., editor, Social insects, volume III, pages 1-244. Academic Press, New York.

Myers, N., Mittermeier, R. A., Mittermeier, C. G., Da Fonseca, G. A., \& Kent, J. (2000). Biodiversity hotspots for conservation priorities. Nature, 403(6772), 853. doi:10.1038/35002501

Paviolo, A., De Angelo, C., Ferraz, K. M., Morato, R. G., Pardo, J. M., Azevedo, F. (2016). A biodiversity hotspot losing its top predator: The challenge of jaguar conservation in the atlantic forest of South America. Scientific reports, 6(1), 1-16. doi:10.1038/srep37147

Pine, R. H. (1994). New mammals not so seldom. Nature, 368(6472), 593593. doi: $10.1038 / 368593 a 0$

Pisno, R. M., Salazar, K., Lino-Neto, J., Serrão, J. E. , \& DeSouza, O. (2019). Termitariophily: expanding the concept of termitophily in a physogastric rove beetle (Coleoptera: Staphylinidae). Ecological Entomology, 44(3), 305-314. doi:10.1111/een.12709

R Core Team. (2020). R: A Language and Environment for Statistical Computing. R Foundation for Statistical Computing.

Reich, P. B., Tilman, D., Isbell, F., Mueller, K., Hobbie, S. E., Flynn, D. F. B., \& Eisenhauer, N. (2012). Impacts of Biodiversity Loss Escalate Through Time as Redundancy Fades. Science, 336(6081), 589-592. doi:10.1126/science.1217909

Ritz, C., Baty, F., Streibig, J. C., \& Gerhard, D. (2015). Dose-Response Analysis Using R. PLOS ONE, 10(12), e0146021. doi:10.1371/journal.pone.0146021

Ritz, C., Jensen, S. M., Gerhard, D. , \& Streibig, J. C. (2020). DoseResponse Analysis Using R. R series. CRC Press, Boca Raton, Florida.

Schiødte, J. M. C. (1853). On some Staphylinidae, found in the nests of termites. Proceedings of the Zoological Society of London, 21, 101 103.

Seevers, C. H. (1957). A Monograph on The Termitophilous Staphylinidae (Coleoptera). Fieldiana: Zoology, 40, 1-334.

Solow, A. R., \& Smith, W. K. (2005). On estimating the number of species from the discovery record. Proceedings of the Royal Society B: Biological Sciences, 272(1560), 285-287. doi:10.1098/rspb.2004.2955

Zilberman, B. (2018). New species and synonymy in the genus Corotoca Schiødte, 1853 (Coleoptera, Aleocharinae, Corotocini). Zootaxa, 4434(3), 547-560. doi:10.11646/zootaxa.4434.3.9

Zilberman, B. (2019). Synopsis of the genus Termitozophilus Silvestri (Coleoptera, Staphylinidae, Aleocharinae, Corotocini). Zootaxa, 4614(1), 95-116. doi:10.11646/zootaxa.4614.1.4

Zilberman, B., Pires-Silva, C. M., Moreira, I. E., Pisno, R. M., and BezerraGusmão, M. A. (2019). State of knowledge of viviparity in Staphylinidae and the evolutionary significance of this phenomenon in Corotoca Schiødte, 1853. Papéis Avulsos de Zoologia, 59, 271-285. https://doi.org/10.11606/1807-0205/2019.59.19

\section{License: Creative Commons CC BY 4.0}

This article was published with open access for distribution under the terms of the Creative Commons Attribution License, which allows unrestricted use, distribution, and reproduction in any medium, provided the original work is properly cited. 